\title{
PENERAPAN KONSEP MAROKO PADA INTERIOR RUANG KELAS TK YWKA MEDAN
}

\author{
${ }^{1}$ Irwansyah, ${ }^{2}$ Arwina Putri Harahap, ${ }^{3}$ Nusa Tari Widya Sumantri \\ ${ }^{1}$ Prodi Desain Interior Fakultas Seni dan Desain Universitas Potensi Utama \\ ${ }^{2,3}$ Mahasiswa Prodi Desain Interior Fakultas Seni dan Desain Universitas Potensi Utama \\ irw.syah23@gmail.com, arwinaputri98@gmail.com, widysumantri99@ gmail.com
}

\begin{abstract}
ABSTRAK
Taman Kanak-Kanak adalah sebuah sarana pendidikan awal bagi anak-anak untuk menempuh pendidikan. Pastinya banyak orang tua yang menginginkan anaknya pada sarana pendidikan yang baik, makanya saat ini banyak bermacam sarana pendidikan awal yang dapat dipilih oleh orang tua untuk anak. Namun semakin banyak macam sarana pendidikan maka orang tua juga harus semakin berhati-hati dalam memilih sarana pendidikan, karena tujuan orang tua mencari sarana pendidikan awal adalah untuk dapat membangun karakterisik dari diri anaknya dengan baik. Suasana yang menyenangkan dalam konteks desain interior di TK adalah suasana yang timbul dari bentuk, warna dan elemen-elemen interior lainnya yang secara psikologis dapat memberi motivasi belajar atau rangsangan kepada anak didik sehingga menunjang perkembangannya dengan sistem pembelajaran yang mampu menggali segala kemampuan anak. Metode yang digunakan dengan memecahkan masalah yang ada pada masa sekarang dilapangan dengan cara mengumpulkan, menyusun, mengklarifikasikan data-data. Selain itu, penelitian ini juga menggunakan metode kombinasi sehingga diperoleh data yang lebih komprehensif, valid, reliable, dan obyektif. Dengan penerapan konsep maroko dan elemen interior dapat berperan dalam menciptakan suasana ruang sesuai dengan fungsinya, juga untuk menunjang semangat dan minat belajar anak Dimana konsep maroko yang diterapkan memiliki warna warni cerah, sangat kaya dengan sejarah dan tekstur dan ditambah dengan ornament membuat suasana kelas bagi anak-anak lebih menarik dan nyaman.
\end{abstract}

Kata Kunci: Interior Kelas, Maroko, Taman Kanak-Kanak

\begin{abstract}
Kindergarten is a means of early education for children to study. Certainly many parents who want their children to have good educational facilities, so at this time there are many different types of early education facilities that can be chosen by parents for children. But the more various kinds of educational facilities, parents also have to be more careful in choosing educational facilities, because the purpose of parents looking for early educational facilities is to be able to build the characteristics of their children well. A pleasant atmosphere in the context of interior design in kindergarten is an atmosphere that arises from the shape, color and other interior elements that can psychologically motivate learning or stimulation to students so as to support their development with a learning system that is able to explore all the abilities of children. The method used by solving existing problems in the field by collecting, compiling, clarifying data. In addition, this study also uses a combination of methods to obtain more comprehensive, valid, reliable, and objective data. With the application of Moroccan concepts and interior elements can play a role in creating a spatial atmosphere in accordance with its function, also to support children's enthusiasm and interest in learning Where the Moroccan concept that is applied has bright colors, is very rich in history and texture and coupled with ornament create a classroom atmosphere for children more attractive and comfortable children
\end{abstract}

Keywords: Interior Classes, Morocco, Kindergarten 


\section{PENDAHULUAN}

Pemberian peerhatian orang tua kepada tumbuh dan berkembangan anak-anak semakin meningkat. Hal ini ditandai dengan adanya tingkat kepedulian orang tua dalam memilih tempat pendidikan terbaik bagi anak-anak mereka. National Association for the Education of Young Children (NAEYC) (2004) mengatakan bahwa emilihan tempat pendidikan yang baik bagi anak-anak terlihat bukan hanya tingkat paling tinggi (Perguruan Tinggi) tetapi tinggal dasar/awal (TK) atau Play group dalam menempuh pendidikan bagi anak mereka.

Warna, bentuk serta elemen interior lainnya dapat memberikan suasana yang menarik dan menyenangkan bagi anak-anak sehingga dapat meningkatkan motivasi belajar anak-anak untuk mengembangkan dan menggali kemampuan anak tersebut. Maka dari itu bangunan TK yang mempunyai banyak sejarah, bangunan yang dibangun pada zaman Belanda ini masih terawat oleh pihak yayasan. Bangunan yang banyak sekali menggunakan kapur pada dinding bangunan. Bangunan ini sangat sayang sekali jika tidak dirawat dan dijaga.

Pada kesempatan kali ini, penulis ingin merancang atau merubah desain dalam ruangan taman kanak-kanak tanpa mengurangi unsur kanak-kanaknya. Nah, disini kami akan merubah konsep dalam ruangan taman kanak-kanak ini menjadi konsep Maroko. Agar anakanak didalam kelas/ruangan terasa nyaman dan tidak bosan.

Para desainer interior banyak memilih dan menjadikan style dari interior maroko sebagai style favorit meraka dikarenakan gaya interior maroko mempunyai bentuk dan warna berani. Style interior maroko disajikan dengan ekspresi dari berbagai sejarah berbagai negara dengan memperhatikan tekstur, detail dan geometri pada bangunan negara tersebut. Gaya interior maroko juga dipengaruhi dari unsur-unsur agama dan budaya negara tersebut, hal ini dapat dilihat dari bangunan tradisional dan modern sebuah rumah pada setiap negara. Dengan bentuk dan dengan warna merah serta adanya sentuhan etnik dan dekoratif, menjadikan gaya interior maroko terkesan eksotis, mewah dan berani.

\section{I.1. Desain}

Desain adalah sesuatu benda dibuat berdasarakan sebuah rancangan pola, yang dimana pola tersebut jadi dasar dalam membuat benda tersebut. Bangunan, furniture, produk dan pakaian adalah sebuah benda yang sudah dibuat melalui proses awal dari sebuah desain. Untuk melakukan proses pembuatan sebuah desain diperlukannya unsurunsur yang agar menjadi sebuah perhitungan rasa dan pertimbangan serta hal lainnya. Jadi sebuah desain dapat dikatakan suatu bentuk yang dihasilkan dari beberapa unsur dengan memperhatikan berbagai pertimbangan di dalamnya. Menurut John Heskett (2002) "Design is to design a design to produce a design" dimana terdapat empat kata desain. Kata desain pertama, desain sebagai sebuah kata benda (noun) dengan maksud desain sebagai sebuah konsep secara keseluruhan. Kata desain kedua sebagai kata (Verb) dimana pada kata desain ini merujuk pada sebuah kegiatan. Kata desain ketiga dianggap sebagai sebuah konsep/ide, dan sedangkan pada kata desain keempat, desain adalah sebuah produk akhir atau hasil akhir.

Menurut surbarniati (2001:1) desain adalah sebuah rancangan atau perancangan. English-Indonesian Dictionary, desain adalah pembuatan pola atau merencanakan (Echols, 1990:177). Agus Sachari (1984:18) memberikan artian desain adalah sebuah gagasan awal, perencanaan pola, rancangan dan penyiapan segala sesuatu dalam membuat 
suatu benda atau produk. Desain adalah suatu pola, motif, corak dan kerangka dalam membuat bentuk dari bangunan (Kamus besar Indonesia, 2001:257).

\section{I.2. Desain Interior}

Sejarah tentang desain interior tidak ada yang mengetahui pasti kapan dan darimana mulainya. Namun keberadaan penerapan ilmu tentang desain interior banyak ditemukan pada sejarah peradaban manusia, terlihat banyaknya bukti-bukti peninggalan sejarah peradaban manusia yang keberadaannya dapat dilacak. Gambaran nyata peradaban terlihat pada temuan-temuan artefak saat itu. Pola perkembangan kebudayaan masing-masing terlihat berbeda.

Subarniati (2001:1) mengatakan interior adalah sebuah tatanan perabot yang ada di dalam gedung (sebuah ruang). Interior adalah sebuah tatanan ruang yang terdapat unsur keindahan dari bermacam aspek, dimana hasil tatanan karya seni tersebut dapat menghasilkan kepuasan tersendiri bagi penghuni ruang, yaitu kepuasan spiritual dan fisik (Suptandar, 1992:2). Echol (2003:327) di dalam kamus Indonesia-Inggris menyebutkan bahwa ruang merupakan bagian dari dalam rumah disebut interior.

Untuk memecahkan permasalahan manusia terkait dengan sebuah bangunan, seorang desainer dapat menerapkan ilmu tentang desain interior sebagai kreatifitas dan solusi permasalah manusia tersebut. Kreatifitas dan solusi itu dapat dilihat dari penerapan kombinasi tata letak, vegetasi dan warna sehingga terciptalah sebuah lingkungan dengan kombinasi elemen yang lebih baik sehingga membuat meraka lebih nyaman di dalam ruangan tersebut.

\section{I.3. Ruang Kelas}

Suatu ruangan dalam bangunan sekolah, berfungsi sebagai tempat untuk kegiatan tatap muka dalam proses kegiatan belajar mengajar (KBM). Ruangan kelas ini terdiri dari meja siswa, kursi siswa, meja guru, lemari kelas, papan tulis, serta aksesoris ruangan lainnya yang sesuai. Ruang kelas juga menjadi salah satu faktor yang mempengaruhi proses belajar para murid atau mahasiswa dalam menerima suatu pelajaran dan mempengaruhi pengajar dalam menyampaikan pelajaran.

Menciptakan ruang kelas yang menyenangkan akan membantu berlangsungnya proses pembelajaran. Salah satu unsur dari pengelolaan kelas adalah penataan kelas. Penataan kelas memerlukan perhatian dan perencanaan yang sungguh-sungguh dalam proses pembelajaran. Ruangan kelas yang ditata dengan baik, akan membuat peserta didik menjadi nyaman, sehingga berkonsentrasi untuk belajar. Penataan ruangan kelas perlu dilakukan untuk menciptakan ruangan kelas yang nyaman dengan memperhatikan standarisasi yang ada.

Standarisasi ruang kelas yang layak perlu ditetapkan. Hal ini bertujuan untuk meningkatkan kenyamanan dalam pembelajaran, karena ruang kelas mempengaruhi pembelajaran untuk mencapai tujuan. Ruangan yang tidak nyaman, memicu munculnya kepadatan. Kepadatan yang terjadi dalam ruang kelas tersebut memiliki dampak yang cukup berpengaruh. Jika kepadatan menurun, kondisi fisik maupun perilaku pada manusia dapat dikatakan normal. Sedangkan jika kepadatan meningkat, menimbulkan penurunan kondisi fisik yang berakibat hilangnya mood. 


\section{I.4. Taman Kanak-Kanak}

Taman kanak-kanak (TK) adalah jenjang pendidikan anak usia dini (usia 6 tahun atau dibawahnya)dalam bentuk pendidikan formal.Kurikulum TK ditekankan pada pemberian rangsangan pendidikan untuk membantu pertumbuhan dan perkembangan jasmani dan rohani agar anak memiliki kesiapan dalam memasuki pendidikan lebih lanjut.Lama masa belajar seorang murid di TK biasanya tergantung pada tingkat kecerdasannya yang dinilai dari rapor per semester. Secara umum, untuk lulus dari tingkat program di TK selama (dua) tahun, yaitu :

a. TK 0 (nol) Kecil (TK Kecil) selama 1 (satu) tahun

b. TK 0 (nol) Besar (TK Besar) selama 1 (satu) tahun

Di Indonesia, seseorang tidak diwajibkan untuk menempuh pendidikan di TK. YWKA (Yayasan Wanita Kereta Api) adalah nama sekolah yang dijadikan sebagai permasalahan desain interior ruang taman kanak-kanak. Dengan demikian, dapat diambil kesimpulan dari Desain Interior Taman Kanak-Kanak YWKA di Jalan Bengkel adalah mewujudkan bangunan interior pada bangunan arsitektural yaitu sebuah Taman KanakKanak YWKA yang terletak di jalan Bengkel.

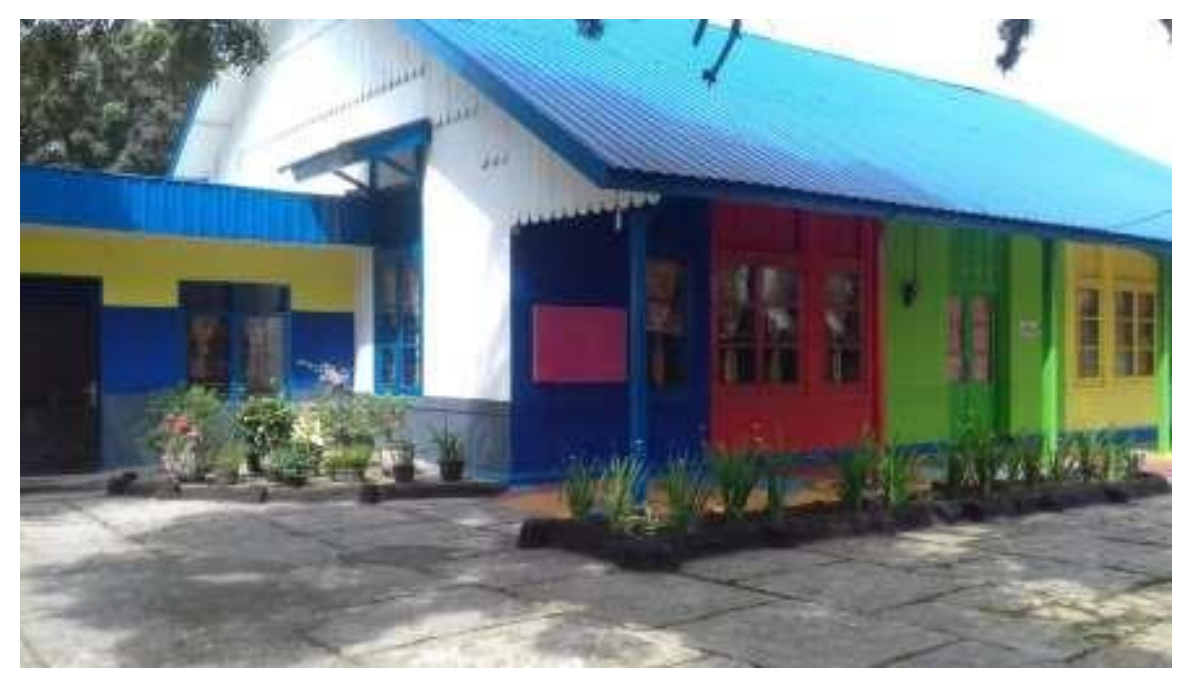

Gambar 1. Taman Kanak YWKA Medan

Sumber : Dokumen Pribadi - 2020

\section{I.5. Konsep Maroko}

Konsep yang mengacu pada negeri maroko, atau yang biasanya di sebut dengan marrocan style. Di dalamnnya ramai dengan warna warni cerah, sangat kaya dengan sejarah dan tekstur. Mainkan warna-warna ceria berupa cushion bermotif etnik Maroko yang memiliki karakter manis dan chic. Agama dan budaya adalah hal yang mempengaruhi terbentuknya Arsitektur tradional Maroko. Elemen-elemen yang indah serta lengkungan yang menawan pada gaya arsitektur tradisional maroko ini yang membuatnya paling dikenali. Penggunaan warna yang cemerlang, berani hingga lembut dan halus membuat gaya interior maroko banyak digunakan. Warna lautan atau bantaran padang pasir adalah skema warna yang paling sering digunakan. Bentuk geometris yang diterapkan pada model ubin, dekorasi lantai, pintu serta jendela membuat suatu aksen 
yang karya seni yang menawan. Pengguna perabot yang terbuat dari logam atau metal juga menghiasi interior tradional maroko.

Metode yang digunakan dengan memecahkan masalah untuk melakukan analisa permasalahan pada penelitian ini adalah menggungganakan metode kualitatif. Dengan mengumpulkan, menyusun dan mengklarifikasikan data-data. Data yang diperlukan merupakan data yang relevan dan menunjang untuk perancangan ruang (interior) kelas TK YWKA Medan.

Dalam penelitian ini juga menggunakan metode campuran yaitu metode kualitatif dan metode kuantitatif. Menurut pendapat Sugiyono (2011:404), metode penelitian kombinasi adalah suatu metode penelitian yang mengkombinasikan atau menggabungkan antara metode kuantitatif dan metode kualitatif untuk digunakan secara bersama-sama dalam suatu kegiatan penelitian, sehingga diperoleh data yang lebih komprehensif, valid, reliable, dan obyektif. Setelah mendapatkan data, peneliti menggunakan proses desain (Rosemary Kilmer \& W. Otie Kilmer, 2014 : 178) yaitu proses analisis dan proses sintesis.

Pada proses analisis ini merupakan suatu tahapan programming, dimana pada tahapan ini dilakukan suatu proses analisa permasalahan dengan data-data yang sudah dikumpulkan. Sedang pada proses sintesis adalah tahapan desain, dimana pada tahapan ini adalah tahapan lanjutan yang nanti hasilnyaberupa beberapa alternatif solusi dari permasalahan yang ditemukan pada tahapan programming. Sehingga alternatif yang terbaik yang akan menjadi pilihan untuk memecahkan permasalahan secara optimal.

\section{STUDI LITERATUR}

Taman Kanak-Kanak adalah sebuah sarana pendidikan awal bagi anak-anak untuk menempuh pendidikan. Pastinya banyak orang tua yang menginginkan anaknya pada sarana pendidikan yang baik, makanya saat ini banyak bermacam sarana pendidikan awal yang dapat dipilih oleh orang tua untuk anak. Namun semakin banyak sarana pendidikan maka orang tua harus semakin berhati-hati dalam memilih sebuah sarana pendidikan bagi anak, karena tujuan orang tua mencari sarana pendidikan awal adalah untuk dapat membangun karakterisik dari diri anaknya dengan baik.

Untuk menciptakan sebuah ruang kelas yang bukan hanya untuk membangun karakterisik tetapi diperlukan juga sebuah ruang yang nyaman, aman sehingga menarik minat belajar anak dan membuat rancangan interior ruang kelasnya baik untuk anak dapat menjadi solusi bagi penyedia sarana pendidikan. Oleh karena itu terdapat beberapa penelitian yang terkait untuk dijadikan acuan dalam penelitian ini. Pertama penelitian dari Handoko Sindunoto (2013) dalam penelitiannya yang "Pengaruh desain interior kelas terhadap minat belajar siswa taman kanak-kanak ciputra di surabaya", dimana dari Handoko Sindunoto mengatakan sebuah ruang kelas pada sarana pendidikan awal haruslah dapat memberikan kontribusi yang positif agar pencapaian target kurikulum dengan meningkatkan minat belajar dari para siswa dalam melaksanakan proses belajar mengajar. Kedua, penelitian dari Kresna Adi Purnomo (2010) dengan judul penelitian "Desain Interior Sekolah Taman Kanak Kanak Cuypers Global School Di Surakarta (Dengan Pendekatan Konsep Modern)", dalam penelitiannya ini mengatakan dalam mewujudkan ruang kelas sekolah taman kanak-kanak harus memperhatikan elemenelemen interior yang mengacu pada fungsi dan kebutuhan pengguna di dalam kegiatan belajar mengajar, penggunaan bentuk-bentuk furnitur yang dapat memacu kreatifitas 
anak-anak dan penggunaan warna serta dekorasi yang baik dapat mempengaruhi kognitif, psikomotori dan afektif si anak dalam berkreativitas.

\section{PEMBAHASAN}

Pengaruh lingkungan fisik dan psikis adalah hal yang besar dalam mempengaruhi perkembangan diri anak seperti tingkat kreativitasnya. Ruang kelas atau ruang belajar yang sempit, gelap dan pengap dapat mempengaruhi kenyamanan seorang anak ketika dalam belajar dan bermain. Selain lingkungan yang indah dan nyaman, anak-anak juga mempunyai kebutuhan lingkungan yang membuat mereka lebih kreatif. Proses belajar yang diinginkan seorang siswa taman kanak-kanak adalah proses yang membuat mereka tertarik untuk belajar, dikarenakan seorang siswa taman kanak-kanak lebih tertarik dengan hal yang memiliki sifat visual. Dengan kebutuhan lingkungan yang menarik bagi anak-anak dapat mengoptimalkan perkembangan dan pertumbuhan anak sehingga mendorong kecerdasan emosional, intelektual, sosial dan psikologis anak tersebut.

\section{Elemen Pembentuk Ruang Ruang Belajar/Kelas}

Lantai merupakan area favorit anak untuk bermain, karena adanya kecenderungan anak mengambil mainan yang jatuh ke lantai dan memasukannya kedalam mulut, maka sebaiknya lantai dilapisi alas yang bagus, tidak licin dan berkesan hangat. Hal ini diperkuat dengan adanya sampel data yang diambil melalui kuesioner yang diberikan kepada Wali kelas atau Guru pada TK YWKA Medan, kuesioner yang diberikan tentang area/tempak anak dalam melakukan aktivitas belajar dan bermain. Dari data kuesioner tersebut lantai adalah area favorit anak dimana anak dengan usia 4-6 tahun suka bermain sambil tidur-tiduran. Maka dari itu lantai untuk ruang kelas sebaiknya kuat, tidak licin, dan pemeliharaaannya harus mudah, demikian pula untuk dinding dan plafon. Dalam pemilihan penggunaan cat juga harus diperhatikan. Cat yang baik adalah yang tidak mengandung zat-zat tertentu yang berbahaya bagi kesehatanPlafon pada ruang belajar dan bermain anak diutamakan dari sisi fungsional, karena aktivitas di dalamnya membutuhkan konsentrasi. Material yang sesuai adalah eternit polos, tripleks dan berbagai jenis softboard serta beton ekspos dengan finishing sederhana.

\section{Elemen Estetis Ruang Belajar}

Dekorasi kelas bukan hanya tambahan untuk kegiatan belajar mengajar, tetapi sebagai kontribusi untuk kenyamanan dalam sekolah dan memunculkan imajinasi anakanak. Elemen estetis dapat terlihat estetis jika disusun atau ditata dengan rapi dan teratur, elemen estetis bisa dihasilkan oleh siswa atau dengan foto siswa yang dipasang pada tempat yang terlihat.

Dengan bentuk visualisasi hasil karya siswa tersebut dapat membentuk sikap dan kepribadian anak yang mempunyai fungsi-fungsi jiwa yang meliputi fantasi, sensitivitas, kreativitas dan ekspresi, sehingga ruang belajar dengan memperhatikan elemen estetisnya dapat menjadi hal yang menarik bagi anak. 

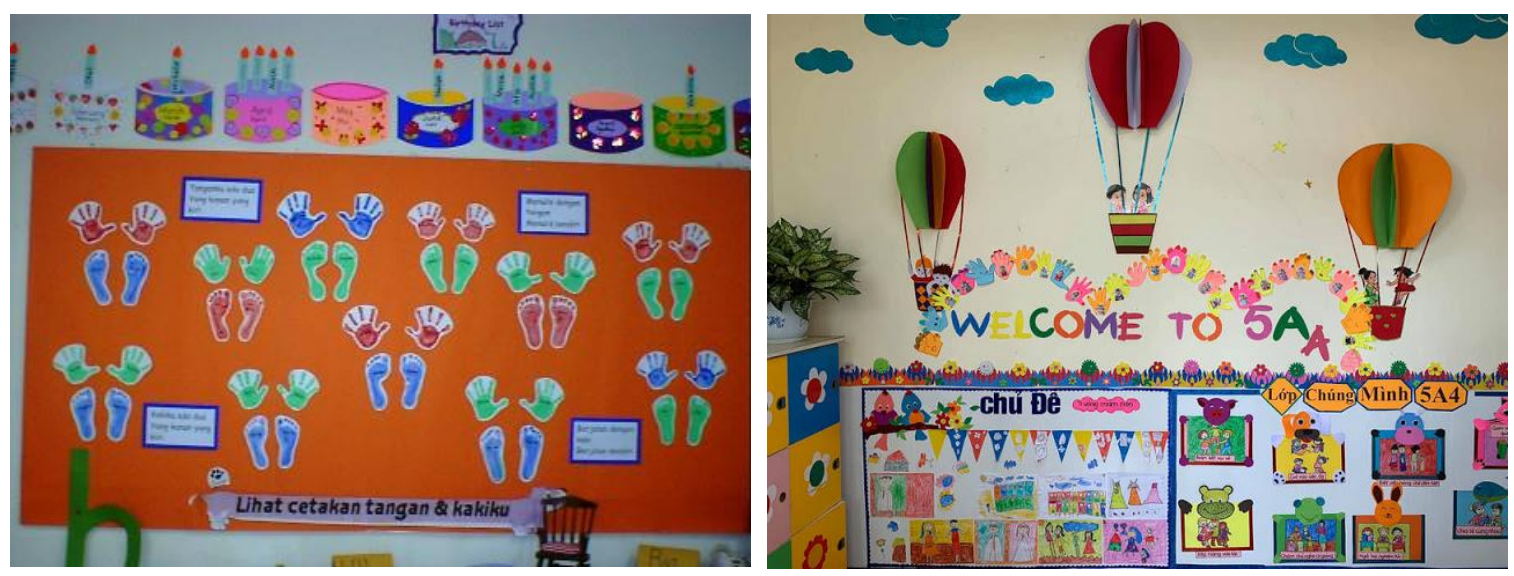

Gambar 2. Contoh Elemen Estetis Dekorasi Karya Hasil Siswa

Sumber :Internet -2020

\section{Furniture}

Furniture merupakan kebutuhan penting bagi penyelenggaraan TK. Jenis dan ukuran Furniture disesuaikan dengan kebutuhan pelaksanaan pendidikan dan anak didik TK. Furniture- Furniture (meja, kursi, rak untuk alat pendidikan, dan rak simpan untuk barang milik anak didik) tersebut hendaknya dicat dengan warna muda yang menarik atau dengan pelitur biasa. (Astrini, 2005: 4, 9-10)

Berikut adalah rekomendasi ukuran dari perabot yang cocok digunakan untuk mengisi ruang kelas/belajar taman kanak-kanak;

Tabel 1. Rekomendasi ukuran dari perabot ruang kelas TK

(sumber : Astrini, 2005: 4, 9-10)

\begin{tabular}{|c|l|c|c|c|}
\hline \multirow{2}{*}{ No } & \multirow{2}{*}{ Jenis Barang/Produk/Perabot } & \multicolumn{3}{|c|}{ Diameter } \\
\cline { 3 - 5 } & & Panjang & Lebar & Tinggi \\
\hline 1 & Meja anak & $120 \mathrm{~cm}$ & $75 \mathrm{~cm}$ & $47-50 \mathrm{~cm}$ \\
\hline 2 & Kursi anak & $32-35 \mathrm{~cm}$ & $27-30 \mathrm{~cm}$ & $30 \mathrm{~cm}$ \\
\hline 3 & Lemari alat pendidikan & $150 \mathrm{~cm}$ & $40 \mathrm{~cm}$ & $65 \mathrm{~cm}$ \\
\hline 4 & Lemari Penyimpanan/Loker & $30 \mathrm{~cm}$ & $30 \mathrm{~cm}$ & $\pm 100 \mathrm{~cm}$ \\
\hline 5 & \multicolumn{3}{|l}{ Ketinggian meja/rak untuk kegiatan yang dilakukan sambil berdiri adalah sekitar } \\
\end{tabular}

\section{Interior pada Ruang Kelas Taman Kanak-Kanak YWKA Medan}

Santrock (2007:561) mengatakan untuk mendorong hubungan antar siswa diperlukan penataan ruang kelas, ruang menggambar/belajar menggunakan gaya cluster dengan jumlah siswa sebanyak 68 anak duduk bersama dan kerja kelompok dapat membantu kegiatan proses belajar kooperatif. Dengan posisi duduk menghadap ke depan atau menghadap ke guru, proses belajar seperti ini dapat membatasi interaksi anak dan pergerakan antar anak dan antar guru, penataan ini berkesan kaku dan formal (Santrock, 2007:561). Jarak antar meja satu dengan meja lainnya yakni $120 \mathrm{~cm}$ di samping dan 75 
cm di belakang. Jarak antar meja ini cukup lebar untuk sirkulasi dan tempat duduk siswa (Ruth, 2000:12).

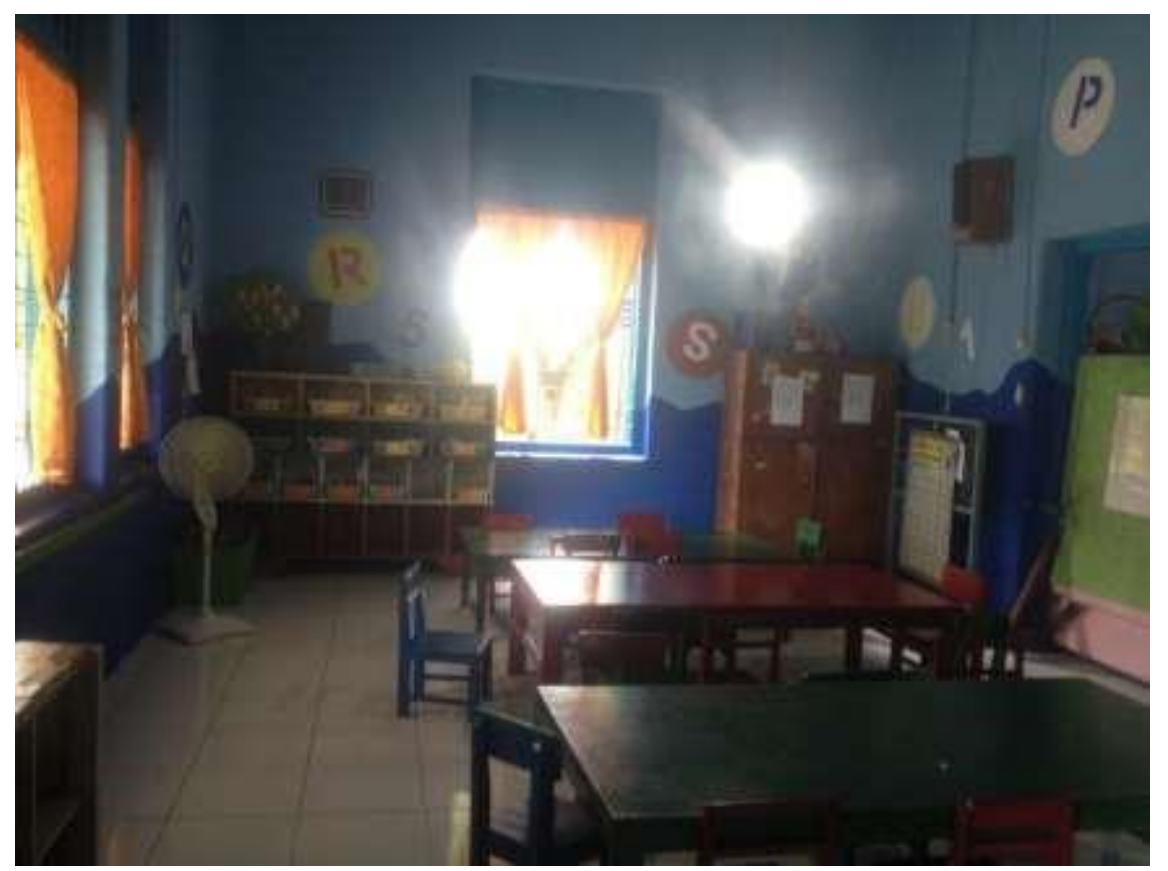

Gambar 3. Ruang Kelas Taman Kanak YWKA Medan

Sumber : Dokumen Pribadi - 2020

Setiap sudut ruangan kelas terdapat lemari/loker penyimpanan tas untuk siswa yang tidak jauh dari pintu keluar masuknya ke ruangan kelas. Kursi dan meja siswa yang berdekatan dengan lemari/loker penyimpanan tas siswa dapat mengganggu sirkulasi udara sehingga pergerakan siswa kurang leluasa dan menjadi kurang nyaman. Dimana ruang kelas TK YWKA Medan, jumlah yang menggunakan ruang tersebut adalah rata-rata jumlah sekitar 20-25 anak dan 1 Guru, sehingga sirkulasi yang dihasilkan kurang jika dilihat dari karakter anak yang sangat aktif.

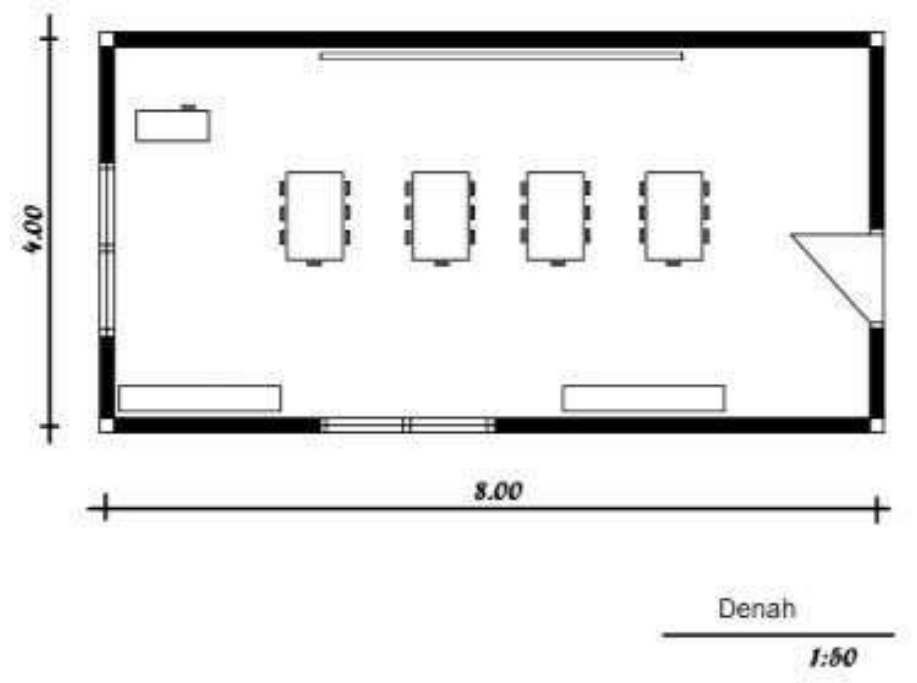

Gambar 4. Layout Ruang Kelas Taman Kanak YWKA Medan Sumber : Dokumen Pribadi - 2020 
Menurut Roth (1966:50) mengatakan munculnya sebuah imajinasi anak-anak bukan hanya karena tambahan dekorasi ruang kelas/belajar saja tetapi juga sebagai peran kenyamanan bagi anak-anak tersebut. Dekorasi ruang kelas bisa dihasilkan oleh siswa atau dengan foto siswa yang dipasang pada tempat yang terlihat dan disusun dengan teratur. Sari (2005:89) menyebutkan seorang siswa taman kanak-kanak lebih tertarik dengan hal yang memiliki sifat visual yang membuat mereka lebih kreatif.

Elemen dekorasi yang estetis seperti ornament dapat diterapkan pada interior ruang kelas TK YWKA untuk menambah nilai estetis. Selain itu penerapan elemen estetis dapat membuat anak-anak merasa nyaman, dan membuat daya Tarik merakaakan sesuatu yang bersifat visual.

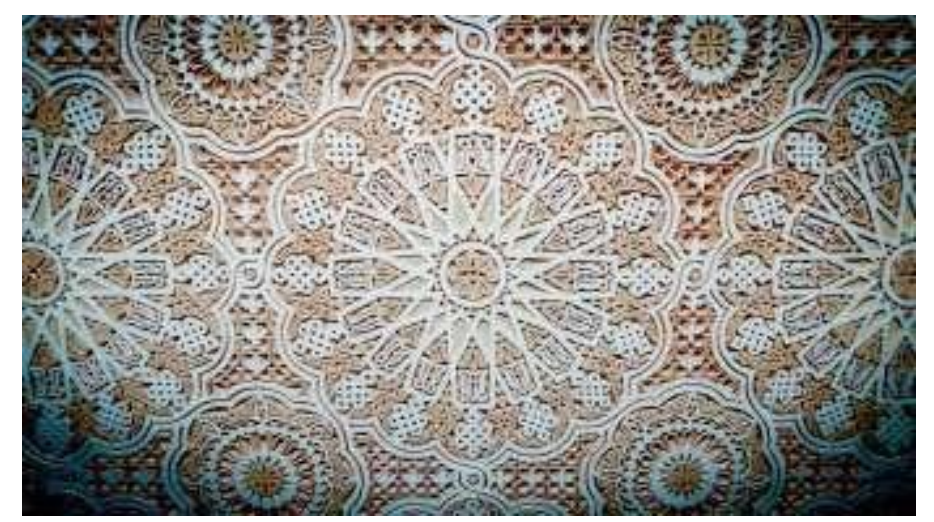

Gambar 5. Ornamen Pada Plafon Ruang Kelas Taman Kanak YWKA Medan Sumber : Dokumen Pribadi - 2020

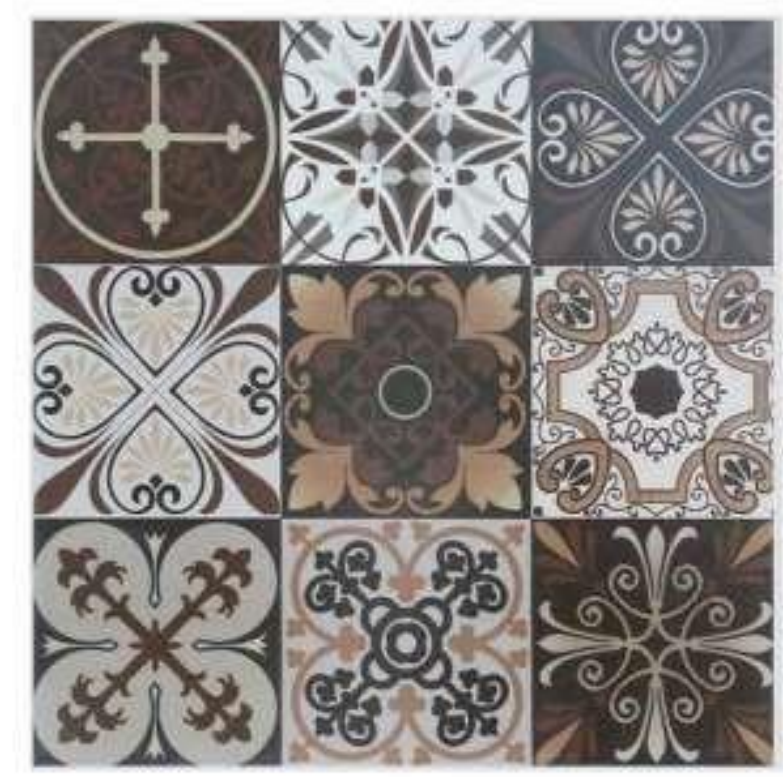

\section{Gambar 6. Ornamen Lantai Ruang Kelas Taman Kanak YWKA Medan} Sumber : Dokumen Pribadi - 2020

Memberikan sentuhan ornamen pada lantai, dinding dan plafon dapat menambah ruang kelas menarik untuk anak-anak. Penerapan ornamen tersebut dapat menumbuhkan suasana keindahan dan membuat suasana ceria. Dengan ditambahnya penerapan ornamen 
pada interior ruang kelas Taman Kanak YWKA Medan dapat minimbulkan aktivitas ceria yang tercipta dapat meningkatkan kreatifitas pada anak dan anak-anak tidak akan merasakan jenuh dan bosan ketika melakukan proses belajar.

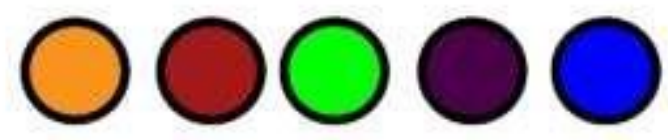

Gambar 7. Palet Warna Ruang Kelas Taman Kanak YWKA Medan Sumber : Dokumen Pribadi - 2020

Pemilihan warna pada ruang kelas yang tepat dapat memenuhi kebutuhan lingkungan ruang belajar anak. Tujuan warna yang tepat dapat meningkatkan daya tarik dan dorangan untuk mau dan semangat belajar anak yang dapat membuat perkembangan diri pada anak meningkat (Optimal). Berikut hasil desain penerapan sebuah konsep yang dapat meningkatkan daya tarik untuk semangat belajar dan berkreatifitas bagi anak.
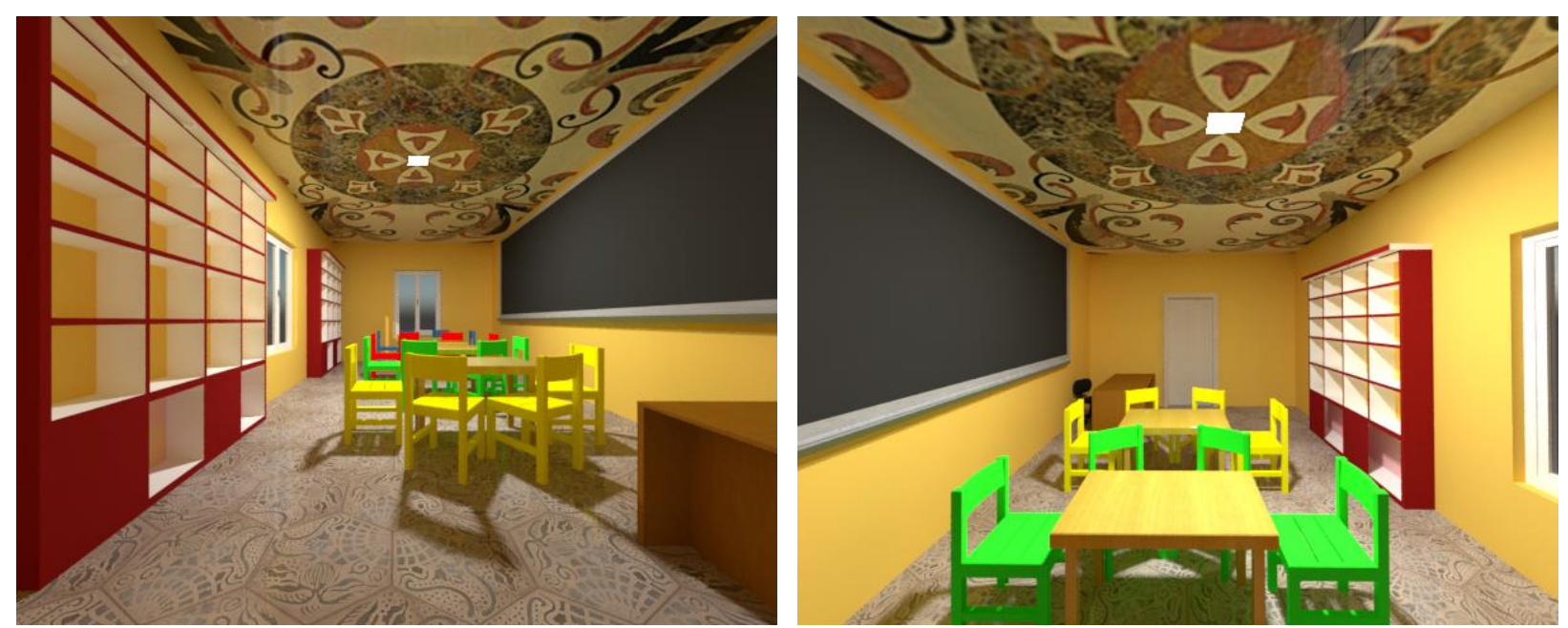

Gambar 8. Desain Ruang Kelas Taman Kanak YWKA Medan Sumber : Dokumen Pribadi - 2020

Hasil rancangan desain diatas dapat membuat semangat belajar siswadan dapat mendorong serta meningkatkan kreatifitas anak. Dimana pada rancangan diterapkan sebuah konsepyang dapat menumbuhkan semangat, pemberian ornamen motif melayu. Ornamen bukan hanya sebagai bentuk seni hias yang bertujuan sebagai suatu keindahan dalam ruang tetapi juga dapat memberikan semangat berkreativitas, selain itu juga memberikan inovasi serta memberikan pembelajaran tentang salah satu unsur budaya yang ada di Kota Medan. Penerapan warna juga untuk memberikan stimulasi motoric dalam meningkatkan daya kreatifitas anak, memberikan suasana ceria, berani dan semangat belajar.

\section{KESIMPULAN}

Potensi seorang anak dapat berkembang dari pendidikan awal yang diberikan karena pada usia 4-6 tahun sensitivitas dan prilaku anak stabil dan anak seusia itu sudah dapat mengenali hal-hal baru. Pengaruh lingkungan fisik dan psikis adalah hal yang besar dalam mempengaruhi perkembangan diri anak seperti tingkat kreativitasnya. Memberikan ruang kelas/belajar dan kebutuhan lingkungan yang menarik bagi anak-anak dapat 
mengoptimalkan perkembangan dan pertumbuhan anak sehingga mendorong kecerdasan emosional, intelektual, sosial dan psikologis anak. Dengan penerapan konsep maroko pada interior ruang kelas TK YWKA Medan dapat memenuhi kebutuhan siswa, dikeranak bentuk dan warna dari style interior maroko dan sentuhan elemen estetis menjadikan ruangan sangat berani dan menyenangkan bagi siswa, sehingga ruangan kelas/belajar menjadi nyaman, bebas dan aman bagi siswa dan dapat meningkatkan semangat belajar serta berkreativitas siswa.

\section{DAFTAR PUSTAKA}

[1] Adi Purnomo, Kresna (2010). Desain Interior Sekolah Taman Kanak Kanak Cuypers Global School Di Surakarta (Dengan Pendekatan Konsep Modern). Universitas Sebelas Maret

[2] Astrini, Wulan. 2005. Pengaruh Interior Ruang Belajar dan Bermain Terhadap Kognitif. Jurnal Dimensi Interior, 3(1), 1- 14.

[3] Darmasetiawan, Christian, dan Puspakesuma, Lestari. (1991). Teknik Pencahayaan dan Tata Letak Lampu, Jilid 1. Jakarta: Gramedia Widiasarana.

[4] John Heskett (2002). Design: A Very Short Introduction. New York: Oxford University Press

[5] John W. Santrock (2007). Perkembangan Anak. Jilid 1 Edisi kesebelas. Jakarta : PT. Erlangga.

[6] National Association for the Education of Young Children. (2004). 10 Signs of a Great Preschool (on-line). https://www.naeyc.org/ diakses pada tahun 2020.

[7] Sari, Sriti Mayang. 2005. Peran Ruang Dalam Menunjang Perkembangan Kreativitas Anak. Jurnal Dimensi Interior 3(1), 80-94.

[8] Setiawan, Budi dan Grace Hartanti. (2014). Pencahayaan Buatan Pada Pendekatan Teknis Dan Estetis Untuk Bangunan Dan Ruang Dalam. H U M A NIO R A Vol.5 No.2 Oktober 2014

[9] Sindunoto, Handoko (2013). Pengaruh desain interior kelas terhadap minat belajar siswa taman kanak-kanak ciputra di Surabaya. Dimensi Interior, VOL. 11, NO. 1, JUNI 2013, 22-30. Universitas Kristen Petra.

[10] Sugiyono. 2011. Metode Penelitian Kuantitatif, kualitatif dan R \& D. Bandung: Alfabeta 